\title{
Isolation and Culture of a Marine Bacterium Degrading the Sulfated Fucans from Marine Brown Algae
}

\author{
Valérie Descamps, ${ }^{1}$ Sébastien Colin,${ }_{1}^{1}$ Marc Lahaye, ${ }^{2}$ Murielle Jam, ${ }^{1}$ Christophe Richard, ${ }^{1}$ \\ Philippe Potin, ${ }^{1}$ Tristan Barbeyron, ${ }^{1}$ Jean-Claude Yvin, ${ }^{1}$ Bernard Kloareg ${ }^{1}$
}

\author{
${ }^{1}$ UMR 7139 (CNRS, Laboratoires Goëmar and Université Pierre et Marie Curie), Station Biologique de Roscoff, Place Georges Teissier, \\ 29680 Roscoff, Brittany, France \\ ${ }^{2}$ leurs Organisations et Interactions, INRA, Unité de Recherche sur les Polysaccharides, BP 71627, 44316 Nantes cedex 03 , \\ Brittany, France
}

Received: 24 September 2004 / Accepted: 14 June 2005 / Published online: 16 October 2005

\begin{abstract}
Fucoidans are matrix polysaccharides from marine brown algae, consisting of an $\alpha$-L-fucose backbone substituted by sulfate-ester groups and masked with ramifications containing other monosaccharide residues. In spite of their interest as biologically active compounds in a number of homologous and heterologous systems, no convenient sources with fucanase activity are available yet for the degradation of the fucalean algae. We here report on the isolation, characterization, and culture conditions of a bacterial strain capable of degrading various brown algal fucoidans. This bacterium, a member of the family Flavobacteriaceae, was shown to secrete fucoidan endo-hydrolase activity. An extracellular enzyme preparation was used to degrade the fucoidan from the brown alga Pelvetia canaliculata. End products included a tetrasaccharide and a hexasaccharide made of the repetition of disaccharidic units consisting of $\alpha$-1 $\rightarrow 3$-L-fucopyranose-2-sulfate- $\alpha$ $1 \rightarrow 4$-L-fucopyranose-2,3-disulfate, with the 3-linked residues at the nonreducing end.
\end{abstract}

Keywords: Flavobacteriaceae — fucalean brown algae - fucan oligosaccharides — fucoidan — fucoidanase - marine bacteria

\section{Introduction}

The main matrix polysaccharide of brown algae (Phaeophyta) is alginate, a linear polymer of $\beta$-Dmannuronic acid and its $\mathrm{C}_{5}$ epimer, $\alpha$-L-guluronic acid. Brown algae, especially Fucales, also comprise

Correspondence to: Tristan Barbeyron; E-mail: barboun@ sb-roscoff.fr matrix polysaccharides known as fucoidans, made of sulfated-L-fucose residues (Mabeau and Kloareg, 1987). In the fucoid alga Pelvetia canaliculata fucoidans represent as much as approximately $40 \%$ of the cell wall dry weight (Kloareg, 1984). Fucoidans consist of a continuous spectrum of highly ramified polysaccharides with a complex and still somewhat elusive structure, ranging from high uronic acid, low-sulfate-containing polymers with significant proportions of D-xylose, D-galactose, and D-mannose to highly sulfated homofucan molecules (Kloareg and Quatrano, 1988; Mabeau et al., 1990).

In brown algal zygotes, sulfated fucans are thought to be involved with adhesion to the substratum as well as with cell polarization, through a transmembrane complex reminiscent of the focal adhesions of mammalian fibroblast and epithelial cells (Kropf et al., 1988; Goodner and Quatrano, 1993). Sulfated fucans have also been extensively investigated for their anticoagulant properties, which involve the inhibition of thrombin and/or the activation of antithrombin and heparin factor II (e.g., Millet et al., 1999; Pereira et al., 1999; Thorlacius et al., 2000). In addition, by interfering with cell-cell recognition in mammalian systems, they display a variety of biological activities. They inhibit the acrosomal reaction in human spermatozoa (Mahony et al., 1991, 1993) and block infections by such viruses as the human immunodeficiency virus (Béress et al., 1993; Hoshino et al., 1998), the vesicular stomatitis virus (Mayer et al., 1987), and the herpes simplex virus (Hoshino et al., 1998), as well as by other microbes, such as Plasmodium knowlesi (Dalton et al., 1991). Sulfated fucans are potent inhibitors of smooth muscle cell growth, both in vitro and in vivo (McCaffrey et al., 1992; Logeart et al., 1997), and they display antiproliferative activity in various cancer types, including a 
non-small-cell bronchopulmonary carcinoma line (Riou et al., 1996) and Erhlich carcinoma (Zhuang et al., 1995). Also, sulfated fucans dose-dependently but nonspecifically inhibit selectin-mediated leukocyte rolling and emigration, thus decreasing organ injuries in non infectious models of inflammation (Ley et al., 1993; Wikström et al., 1995; Ostergaard et al., 2000; Linneman et al., 2000). Finally, sulfated fucans may be used in crop disease control since oligomers from sulfated fucans induce systemic resistance in tobacco against tobacco mosaic virus (Klarzynski et al., 2003).

In this context, a reliable fucoidan-degrading enzyme preparation would be highly desirable to obtain oligofucoidans, both to further elucidate the fine chemical structure of fucoidans and to investigate their structure-activity relationships in homologous or heterologous systems. However, only a few attempts were made so far to isolate fucoidandegrading enzymes. In the case of herbivorous molluscs, Thanassi and Nakada (1967) partially purified a fucoidanase with a molecular mass of between $100 \mathrm{kDa}$ and $200 \mathrm{kDa}$ from Haliotus rufescens and $H$. corrugata. These activities hydrolyzed the fucoidan from Fucus gardneri to oligosaccharides ranging from the decasaccharide to L-fucose. Fucoidanases were also partially purified from Pecten maximus (Daniel et al., 1999) but the activity contained in the digestive glands of this mollusc was essentially a highly active and unusually thermal stable exo-fucosidase of $200 \mathrm{kDa}$ (Berteau et al., 2002), mixed with a putative fucoidanase activity (Daniel et al., 1999) as also reported for the bivalve Patinopecten yessoensis (Kitamura et al., 1992). As far as bacteria are concerned, a study of Laminaria-decomposing epiflora indicated that fucoidanase activities are inducible, weak, but not rare in marine bacteria (Uchida, 1995). A number of Vibrio-type, fucoidan-degrading bacteria were isolated from marine sediments (Morigana et al., 1981) and an exo-acting fucoidanase was purified from Vibrio sp. N-5 (Furukawa et al., 1992). Recently, Sakai et al. (2002) isolated from the Japan Sea a marine bacterium, "Fucobacter marina" (Flavobacteriacea), which cleaved various fucoidans from the Laminariales Kiellmaniella crassifolia, Undaria pinnatifida, and Lessonia nigrescens but not from the Fucales Fucus vesiculosus and Ascophyllum nodosum. The enzyme was further characterized as a sulfated fucoglucuronomannan lyase (Sakai et al., 2003a). Finally, a bacterial strain belonging to the family Verrucomicrobiaceae was isolated from the gut of the sea cucumber Stichopus japonicus (Sakai et al., 2003b). This bacterium, Fucophilus fucoidanolyticus, was able to degrade a variety of fucoidans, suggesting it produces a number of fucoidan-digesting enzymes. Interestingly, F. fucoidanolyticus was not able to cleave the fucan of the host sea cucumber (Sakai et al., 2003b).

Altogether, no fucoidan-endohydrolase activity is conveniently available yet to degrade the fucoidans from fucalean brown algae. As Fucales are more likely than Laminariales to provide large amounts of sulfated fucoidans (Mabeau et al., 1990), we thus set out to search for convenient sources of such enzymes. Alginate-extraction plants are known to release liquid effluents that are enriched in brown algal sulfated fucoidans (Fleury and Lahaye, 1993). Muds in the water-treatment facilities used for the cleansing of these effluents could therefore be expected to be good candidates for the occurrence of fucoidan-degrading microorganisms. We here report on the isolation and the characterization, from this latter habitat, of a fucoidan-degrading bacterium. The fucoidanolytic activity from culture supernatant was capable of degrading sulfated fucoidans from various fucoid brown algae.

\section{Materials and Methods}

Preparation of Fucoidans. Thalli of Pelvetia canaliculata (Dcne et Thur.) (1 kg fresh weight) were collected during low tide at Roscoff (Brittany, France), freed from epiphytes, and washed with distilled water. They were crushed in a mortar in the presence of liquid nitrogen and macerated overnight in $1 \mathrm{~L}$ of ethanol/formaldehyde $/ \mathrm{H}_{2} \mathrm{O}$ (80:5:15 vol/vol). Algal fragments were then extracted with $2 \mathrm{~L}$ of ethanol/formaldehyde $/ \mathrm{H}_{2} \mathrm{O}$ followed by $2 \mathrm{~L}$ of acetone. The resulting pellet was dried at $60^{\circ} \mathrm{C}$ and extracted twice for $3 \mathrm{~h}$ at $70^{\circ} \mathrm{C}$ with a $0.01 \mathrm{~N} \mathrm{HCl}$ solution supplemented with $4 \%$ (wt/vol) $\mathrm{CaCl}_{2}$. The extract was filtered, concentrated with a rotary evaporator, and neutralized with ammonium carbonate, and fucoidans were precipitated with 2.5 volumes of ethanol. The precipitate was redissolved in water and freeze-dried (Lyolab ALSL, Secfroid). This crude fucoidan fraction (FS28) typically exhibited a total carbohydrate content of approximately $55 \%$, as assayed colorimetrically according to Tillmans and Phillipi (1929), and the proportion of fucosyl residues was approximately $30 \%$ in dry weight, as measured with the cysteine method (Disches and Schettles, 1948). Sulfate accounted for $26 \%$ of dry weight (as determined from the sulfur content by elementary analysis, CNRS, Service Central d'Analyse, Vernaison, France), whereas the uronic acid content was $2 \%$, using the modified $m$-hydroxydiphenylsulfuric acid method with mannuronic acid lactone as stan- 
dard (Blumenkrantz and Asboe-Hansen, 1973). Unless stated otherwise, this cruder fucoidan fraction was used in all experiments. Alternatively, more purified fucans were obtained from $P$. canaliculata, Ascophyllum nodosum, and Fucus spiralis, using the cetylpyridinium chloride (CPC) purification method as described previously (Mabeau et al., 1990). They contained $32 \%, 28 \%$, and $37 \%$ of fucose and $33 \%, 27 \%$, and $35 \%$ of sulfate, respectively.

\section{Isolation of Fucoidan-Degrading Bacteria.} Muds were collected from the water treatment facility of an alginate extraction plant (DaniscoIngredients, Landerneau, Brittany, France) and precultivation of fucan-degrading bacteria was carried out as follows. Erlenmeyer flasks $(100 \mathrm{ml})$ containing $10 \mathrm{ml}$ of seawater/fucan (SWF) medium, consisting of sterile seawater supplemented with $0.2 \%$ (wt/vol) fucoidan from P. canaliculata (FS28 fraction) were inoculated with $400 \mu \mathrm{l}$ of the muds and incubated aerobically at $22^{\circ} \mathrm{C}$ with shaking at $200 \mathrm{rpm}$ on a rotary shaker (New Brunswick Scientific). Aliquots were taken at daily intervals for 7 days and tested for the presence of fucoidanolytic activity as follows. The culture supernatant $(200 \mu \mathrm{l})$ was added to $2 \mathrm{ml}$ of acid albumin solution $(3.26 \mathrm{~g}$ of sodium acetate, $4.56 \mathrm{ml}$ of glacial acetic acid, and $1.0 \mathrm{~g}$ of bovine serum albumin (Sigma) dissolved in $1 \mathrm{~L}$ of water, $\mathrm{pH}$ adjusted 3.72 to 3.78 ). Failure to develop a white turbidity because of the polysaccharide-albumin interaction indicated the presence of fucoidan-degrading activity (Kitamikado et al., 1990).

Active cultures were then plated onto Petri dishes with ZoBell medium (ZoBell, 1941) containing $0.3 \%$ (wt/vol) fucoidan and solidified by $0.7 \%$ (wt/vol) agar, and incubated at $22^{\circ} \mathrm{C}$ for 1 week. The various colonies were then transferred aseptically into $10 \mathrm{ml}$ of Zobell-Fucan (ZF) medium, consisting of one volume of filtered seawater supplemented with $0.4 \%$ (wt/vol) fucoidan and one volume of ZoBell medium, incubated at $22^{\circ} \mathrm{C}$, and assayed daily for fucoidanase activity (see below). The fucoidan-degrading isolates were subjected to repeated cultivation on ZF medium, eventually leading to the isolation of two different fucoidan-degrading strains, referred to as SW1 and SW5. They were stored at $-80^{\circ} \mathrm{C}$ in $\mathrm{ZF}$ medium.

Biochemical and Molecular Characterization of SW5 Bacterial Strain. The morphological features of strain SW5 were investigated by microscopy (A100PL, Olympus BH-2) with cells in the exponential phase in ZoBell medium. To determinate the respiratory type, bacteria were inoculated in Veillon tubes containing ZoBell medium solidified with $0.6 \%(\mathrm{wt} / \mathrm{vol})$ agar. Oxygen was removed from the medium by boiling. To determine the oxidative or fermentative behaviour, bacteria were inoculated into a modified Hugh and Leifson O-F medium (Hugh and Leifson, 1953; Smibert and Krieg, 1981) containing $0.5 \%$ glucose. Oxidase activity was assayed with disks impregnated with dimethylparaphenylene diamine oxalate (Diagnostic Pasteur). Catalase activity was assayed by mixing one colony from a ZoBell agar plate with a drop of $10 \%(\mathrm{v} / \mathrm{v})$ hydrogen peroxide. Production of flexirubin was assessed by flooding a 4-day plate culture with $5 \mathrm{~N}$ potassium hydroxide followed by the observation of changes in colony color from yellow to red or brown (Reichenbach et al., 1974). Other phenotyping tests were performed using API 20 NE strips (API System, Bio-Mérieux) and Biolog GN microplates (Micromer, France).

The 16S ribosomal DNA sequence of the strain SW5 was determined as previously described for another polysaccharide-degrading marine bacterium (Barbeyron et al., 2001). The 16S rDNA gene was amplified by polymerase chain reaction from the bacterial genomic DNA with the $8 \mathrm{~F}$ primer $\left(5^{\prime}\right.$ AGAGTTTGATCCTGGCTCAG-3') (Hicks et al., 1992) and the 1492R primer (5'-GGTTACCTTG TTACGACTT-3') (Kane et al., 1993). PCR products were cloned in vector pCRII2.1 and both strands of 16S rDNA were sequenced using Texas-red labeled primers with a Vistra 725 sequencer. The sequence, $1,241 \mathrm{bp}$ in length, was analysed for similarities to rDNA sequences in the DNA database. The phylogenetic tree was constructed as previously described (Barbeyron et al., 2001).

Culture of SW5 and Detection of Fucoidanolytic Activity. SW5 was inoculated from a $-80^{\circ} \mathrm{C}$ stock into $10 \mathrm{ml}$ of ZF medium in 250-ml Erlenmeyer flask. After incubation for $48 \mathrm{~h}$ at $20^{\circ} \mathrm{C}$ with vigorous rotary shaking, the culture was transferred to $250 \mathrm{ml}$ of ZF medium in a 1-L Erlenmeyer flask and incubated under the same conditions. The culture was then centrifuged at 2,000 $\mathrm{g}$ for $15 \mathrm{~min}$ and the pellet was suspended in $10 \mathrm{ml}$ of $\mathrm{ZF}$ medium and inoculated into $5 \mathrm{~L}$ of $\mathrm{ZF}$ medium, in a 6.6-L fermenter jar. The culture was maintained for 6 days at $20^{\circ} \mathrm{C}$ (Bioflo 3000, New Brunswick Scientific). The $\mathrm{pH}$ was regulated at 7.85 with $\mathrm{HCl}$ and $\mathrm{NaOH}$ solutions $(1 \mathrm{~N})$ and aeration was $1 \mathrm{vvm}$ (5 $\mathrm{L} / \mathrm{min})$, regulated at $70 \%$ by rotary shaking ranging from 200 to $800 \mathrm{rpm}$.

Attempts to quantitatively assay for fucoidanolytic activity by monitoring the release of fucoidan 
Valérie Descamps et al.: Fucoidan Hydrolase Activity from a Marine Flavobacteriaceae

oligosaccharides by a conventional reducing sugar assay (Kidby and Davidson, 1973) were unsuccessful. Fucoidan-degrading activity was thus monitored by a carbohydrate-polyacrylamide gel electrophoresis (C-PAGE) assay of the release of anionic oligosaccharides, according to the procedure of Zablackis and Perez (1990). Briefly, 0.2\% (wt/vol) fucoidan in $20 \mathrm{mM}$ Tris-HCl buffer ( $\mathrm{pH} 7.5)$ was incubated at room temperature with the enzyme and the products of hydrolysis $(20 \mu \mathrm{l})$ were frozen at $-20^{\circ} \mathrm{C}$ to stop the reaction. Samples were then mixed with the loading buffer $(10 \%$ sucrose and $0.01 \%$ phenol red) and electrophoresed through a $6 \%$ (wt/vol) stacking and a $27 \%$ running, $1-\mathrm{mm}$ thick, polyacrylamide gel in $50 \mathrm{mM}$ Tris- $\mathrm{HCl}, 2 \mathrm{mM}$ EDTA buffer (pH 8.7) and stained with alcian blue followed by silver nitrate (Min and Cowman, 1986). Fucoidanase activity was detected by the occurrence of anionic oligosaccharide bands in the running gel.

At the end of culture, the medium was centrifuged at 5,000 $\mathrm{g}$ for $30 \mathrm{~min}$ and the supernatant (5 L) was concentrated by ultrafiltration with an Aminco cassette (10-kDa cutoff). The cassette was washed with $1 \mathrm{~L}$ of fucoidanase buffer $(\mathrm{pH} 7.5)$ containing $20 \mathrm{mM}$ Tris- $\mathrm{HCl}, 50 \mathrm{mM} \mathrm{NaCl}, 5 \mathrm{mM} \mathrm{MgCl}_{2}$ and $5 \mathrm{mM} \mathrm{CaCl}_{2}$. The retentate $(500 \mathrm{ml})$ was brought to $40 \%(\mathrm{wt} / \mathrm{vol})$ saturation with $(\mathrm{NH})_{2} \mathrm{SO}_{4}$ and precipitated overnight at $4{ }^{\circ} \mathrm{C}$. The suspension was centrifuged at 12,000 $\mathrm{g}$ for $30 \mathrm{~min}$ and the resulting supernatant was brought to $60 \%$ (wt/vol) saturation with $\left(\mathrm{NH}_{4}\right)_{2} \mathrm{SO}_{4}$. After precipitation overnight at $4^{\circ} \mathrm{C}$, the precipitate was collected by centrifugation at 20,000 $\mathrm{g}$ for $1 \mathrm{~h}$, dissolved in approximately $20 \mathrm{ml}$ of fucoidanase buffer, dialyzed (10-kDA cutoff) against the fucoidanase buffer for 2 or 3 days at $4^{\circ} \mathrm{C}$, and stored at $-20^{\circ} \mathrm{C}$. The enzyme optimal $\mathrm{pH}$ and temperature were estimated by hydrolysis of the FS28 fucoidan fraction for $1 \mathrm{~h}$, the ammonium sulfate fraction and the C-PAGE assay over the range 5.0 to 8.0 and 17 to $40^{\circ} \mathrm{C}$, respectively.

Preparation of Fucoidan Oligosaccharides. An aliquot $(8 \mathrm{ml})$ of the partially purified enzyme fraction $\left[40 \%\right.$ to $60 \%\left(\mathrm{NH}_{4}\right)_{2} \mathrm{SO}_{4}$ fraction] was added to $1 \mathrm{~L}$ of $20 \mathrm{mM}$ Tris-HCl buffer $(\mathrm{pH} 7.5)$, $5 \mathrm{mM} \mathrm{MgCl}_{2}, 5 \mathrm{mM} \mathrm{CaCl}_{2}$ and $50 \mathrm{mM} \mathrm{NaCl}$ containing $5 \mathrm{~g}$ of fucoidan from $P$. canaliculata (FS28 fraction) and the mixture was incubated at $25^{\circ} \mathrm{C}$ for $24 \mathrm{~h}$. The hydrolysate was diluted in $20 \mathrm{~L}$ of distilled water and then ultrafiltered on a 10$\mathrm{kDa}$ membrane (Millipore). The filtrate (17 L) was refiltered on a 500-Da membrane (Pall Filtron) with a 2 bars pressure. The filtrate $(\sim 15 \mathrm{~L})$ was concentrated on a rotary evaporator and freeze-dried.
Aliquots $(250 \mathrm{mg})$ of the resulting powder, referred to as OF fraction, were resuspended in distilled water $(5 \mathrm{ml})$ and applied onto a DEAE Sepharose CL6B (Pharmacia, $1.6 \times 10 \mathrm{~cm}, 1.1 \mathrm{ml} /$ min) equilibrated with distilled water. Elution was first performed with water $(330 \mathrm{ml})$, then with a linear gradient of 0 to $2 \mathrm{M} \mathrm{NaCl}(660 \mathrm{ml})$. Fractions (11 ml each) were assayed colorimetrically for total sugars (Thibault, 1979) and the carbohydrate-containing fractions were pooled, concentrated by evaporation, then applied on a BioGel P6 column (Bio-Rad, $4.4 \times 100 \mathrm{~cm}, 1 \mathrm{ml} / \mathrm{min}$ ) equilibrated with $50 \mathrm{mM}$ sodium nitrate, $\mathrm{NaN}_{3} 0.01 \%(1,500 \mathrm{ml})$, and eluted with the same buffer. Detection of carbohydrates was performed by refractometry (ERC 7510). Carbohydrate-containing peaks, referred to as peaks 1 to 4 , were collected, concentrated, desalted on a Sephadex G10 column (Pharmacia, $3.2 \times 100 \mathrm{~cm}$, $1.9 \mathrm{ml} / \mathrm{min}$ ), and freeze-dried.

The neutral monosaccharide composition of the purified oligosaccharide fractions was analysed after hydrolysis and reduction by gas chromatography (Autosystem XL, Perkin Elmer) on an OV-225 column $(30 \mathrm{~m} \times 0.32 \mathrm{~mm}, 0.25 \mu \mathrm{m}, \mathrm{DB} 225 \mathrm{~J}$ and W, USA) according to Blakeney et al. (1983). These fractions $(250 \mu \mathrm{g} / \mathrm{ml})$ were further analyzed by highperformance anion-exchange chromatography (HPAEC) and conductivity detection, using a Dionex chromatograph in the configuration DX500 (Dionex, Sunnyvale, CA) and equipped with an anion micromembrane supressor AMMS, a $50 \mu$ injection loop and an AS11A column $(4 \times 250 \mathrm{~mm})$. Elution was performed at $0.5 \mathrm{ml} / \mathrm{min}$ by a linear gradient from $125 \mathrm{mM}$ to $350 \mathrm{mM} \mathrm{NaOH}$ for $25 \mathrm{~min}$ and 350 $\mathrm{mM} \mathrm{NaOH}$ for $5 \mathrm{~min}$. Desalted fucoidan oligosaccharides were freeze-dried twice with deuterium oxide $(99.9 \% \mathrm{D}$, Aldrich) and dissolved in $1 \mathrm{ml}$ of $\mathrm{D}_{2} \mathrm{O}(100 \% \mathrm{D}, \mathrm{Aldrich})$ to replace exchangeable protons by deuterium. C and H NMR spectra were recorded at $25^{\circ} \mathrm{C}$ with a Bruker ARX 400 spectrometer operating at $100.62 \mathrm{MHz}$ and $400.13 \mathrm{MHz}$. Chemical shifts were assigned relative to internal acetone at $2.225 \mathrm{ppm}$ and $31.45 \mathrm{ppm}$ for $\mathrm{H}$ and $\mathrm{C}$, respectively. Pulse sequences for $1 \mathrm{D}$ and $2 \mathrm{D}$ experiments were used as specified by the manufacturer.

\section{Results}

Isolation and Characterization of a FucoidanDegrading Bacterium. Muds collected from a water-treatment facility for the recycling of the effluents of an alginate extraction plant were searched for the occurrence of fucoidan-degrading bacteria. Of the 51 bacterial strains that were isolated for 
their ability to grow on fucoidan-enriched media, only two, referred to as SW1 and SW5, were active in the crude fucoidan-BSA enzymatic test (Kitamikado et al., 1990). These two strains were maintained on fucoidan-enriched ZoBell medium solidified with agar and then tested in liquid medium for their ability to degrade fucoidans. The SW5 strain, which displayed the higher extracellular fucoidanolytic activity, was retained for further studies.

SW5 appeared as an orange-pigmented, gramnegative, rod-shaped, nonflagellated bacterium, unable to grow on the freshwater Luria Bertani medium (Maniatis et al., 1982). Strain SW5 was shown to be a strictly aerobic, seawater-requiring, chemoorganotrophic and heterotrophic organism, with an oxidative metabolism which used oxygen, but not nitrate, as the electron acceptor. The bacterium synthesized $\beta$-glucosidase and $\beta$-galactosidase but did not synthesize flexirubin, cytochrome oxydase or gelatinase and it was not able to degrade agarose and $\kappa$-carrageenan. In contrast, $\mathrm{l}$-carrageenan was hydrolyzed (data not shown).

The 16S rDNA sequence of strain SW5 was found to be related, with sequence identities of $96 \%$ and $93 \%$, respectively, to those of the strains BSD RB 42 (GenBank Accession No. AY259505) and BSA CS 02 (GenBank Accession No. AY259501), which belong to the Flavobacteriaceae family. In the phylogenetic analysis of its 16S rDNA gene, SW5 16S rDNA clusters with heterologous genes from unidentified strains. This group forms a clade with the psychrophyllic bacteria Psychroserpens burtonensis, Gelidibacter algens and G. mesophilus (Figure 1).

Production of Fucoidanolytic Activity from SW5. To produce fucoidanolytic activity, the SW5 strain was grown in a fermenter in a fucoidanenriched ZoBell medium. The generation time was of $12.5 \mathrm{~h}$ at $20^{\circ} \mathrm{C}$ and the culture medium reached an $\mathrm{OD}_{600 \mathrm{~nm}}$ of approximately 1.0 after 3 days of cultivation (Figure 2A). Fucoidanase activity was detected by C-PAGE in the culture supernatant as early as at the end of the exponential phase and was maintained during the stationary phase (Figure $2 \mathrm{~B}$ ). In contrast, intracellular fucoidanolytic activity was very low throughout the culture (data not shown).

The protein ammonium sulfate precipitate from the culture supernatant of SW5 extensively degraded fucoidans purified with cetylpyridinium chloride from the fucoid alga Pelvetia canaliculata as well as those from two other fucoid algae, Fucus spiralis and Ascophyllum nodosum (Figure 3A). Based on the C-PAGE assay of the release of fucoidan oligomers from the FS28 fucoidan fraction, the optimal $\mathrm{pH}$ and temperature were estimated at 7.5 and $20^{\circ}$ to $25^{\circ} \mathrm{C}$, respectively. Although the digestion profiles depended on the fucoidan under investigation, they were all found to share two low molecular weight components with similar electrophoretic motilities (referred to as bands 3 and 4 on Figure 3A). The kinetics of the degradation of P. canaliculata FS28 fucoidan fraction by the enzyme ammonium sulfate fraction is shown in Figure 3B. Oligofucoidans were detected as early as after $2.5 \mathrm{~min}$ of enzymatic digestion, in the form of several discrete bands, referred to as 3, 2, 8, 9, and 10. With the exception of band 2 , the amount of the high molecular weight fucoidan oligosaccharides rapidly decreased, while new oligofucoidan products appeared (bands 1, 5, 6, and 7). However, the terminal product (band 4) was always present in the reaction medium. No significant increase was observed in the $\mathrm{OD}_{235 \mathrm{~nm}}$ of the reaction mixture (data not shown).

Fractionation of Fucoidan Oligosaccharides. The crude fucoidan from the fucoid alga P. canaliculata (FS28) was hydrolyzed to completion by the ammonium sulfate enzyme fraction and the products were ultrafiltered through a $500-\mathrm{Da}$ membrane (OF fraction in Figure $3 \mathrm{C}$ ), with a recovery of $66 \%$ in mass relative to the mass of the initial substrate. The OF fraction was fractionated by anion-exchange chromatography on a DEAE Sepharose CL6B column, resolving three major peaks (Figure 4A), which, on the basis of their levels in total sugars, represented approximately $87 \%$ of the initial oligosaccharide mixture. The main fucoidan oligosaccharide fraction, which was eluted at 0.6 to $1.6 \mathrm{M} \mathrm{NaCl}$ (fraction numbers 85 to 100 ) and represented $55 \%$ of OF in total carbohydrates, was further fractionated by gel filtration onto a Biogel P6 column (Figure 4B). It consisted of a mixture of unresolved fucan oligosaccharides eluting close to the column void volume as well as of four distinct low molecular mass fractions. Based on their sugar content, these latter oligosaccharides represented approximately $10 \%$ of OF fraction in total carbohydrates, that is, about $7 \%$ of the mass of initial polysaccharide. Whereas the OF fraction contained, besides fucose ( $83.8 \mathrm{~mol} \%$ ), some xylose (5.9 $\mathrm{mol} \%$ ) and galactose $(10.4 \mathrm{~mol} \%)$ as well as traces of mannose and glucose, fucose was the only monosaccharide detected by gas chromatography in the purified oligosaccharide fractions 2, 3, and 4 .

After desalting on a Sephadex G10 column, fractions 3 and 4 appeared homogeneous upon CPAGE analysis (Figure 3C). This was confirmed by high-performance anion-exchange chromatography (HPAEC) analysis. They were eluted essentially 


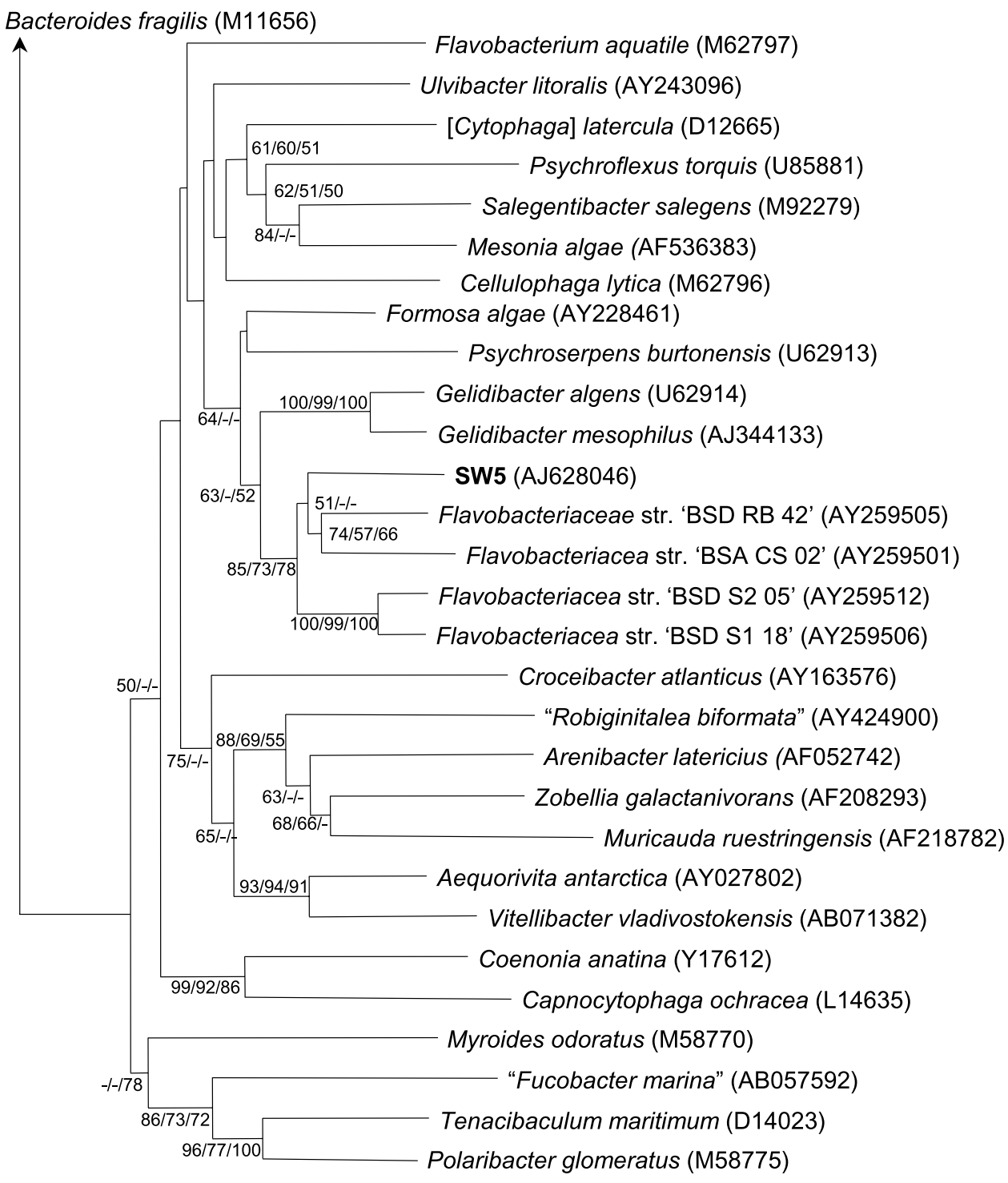

$\underline{0.01}$

Fig. 1. Phylogenetic relationships of strain SW5 to some marine representatives of the family Flavobacteriaceae. Square brackets indicate a generically misnamed taxon and quotation marks indicate a name not yet validated. Accession numbers of $16 \mathrm{~S}$ rDNA sequences are given in brackets. The topology shown is the tree obtained using the neighborjoining method (Jukes and Cantor distance correction). Numbers at the nodes refer to the bootstrap values (100 replicates) as obtained in distance, maximum-likelihood, and maximum parsimony analyses, respectively, while dashes instead of numbers indicate that the node was not observed in the corresponding analysis. The scale bar represents the expected number of changes per sequence position.

as single peaks, with retention times of 18.5 and $13.2 \mathrm{~min}$, respectively (Figure 4C). In contrast, although fractions 1 and 2 appeared as homogeneous by C-PAGE analysis (Figure 3C), they featured several peaks on HPAEC chromatography, with their main components eluting at 19.9 and 20.9 min, respectively (Figure 4C). Discrete bands on C-PAGE gels may thus contain more than one fucoidan oligosaccharide, with various structures, but having the same electrophoretic motility.
NMR Analysis of Fucoidan Oligosaccharides. From its COSY and HMQC NMR spectra, oligosaccharide 4 featured chemical shifts assignable to five different $\alpha$-L-fucopyranosyl residues (Bock et al., 1984), referred from $\boldsymbol{a}$ to $\boldsymbol{e}$ (Table 1). The ROESY spectrum (Figure 5) showed cross-peaks from $\mathrm{H} 1$ of residue $\boldsymbol{b}$ with $\mathrm{H} 3$ of residue $\boldsymbol{d}(\boldsymbol{b} 1 / \boldsymbol{d} 3)$, from $\mathrm{H} 1$ of residue $\boldsymbol{d}$ to $\mathrm{H} 4$ of residue $c(\boldsymbol{d 1} / \boldsymbol{c} 4)$, and from $\mathrm{H} 1$ of residue $\boldsymbol{c}$ to $\mathrm{H} 3$ of residues $\boldsymbol{a}$ and $\boldsymbol{e}$. As previously reported for 3-linked sugars in the 


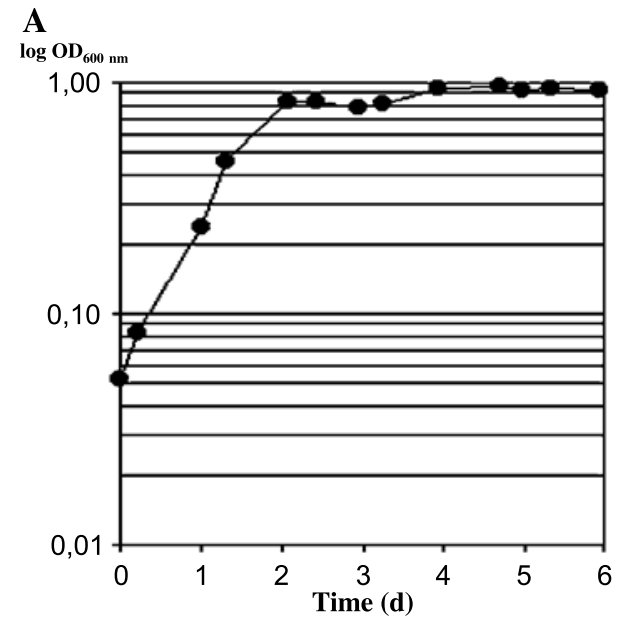

B

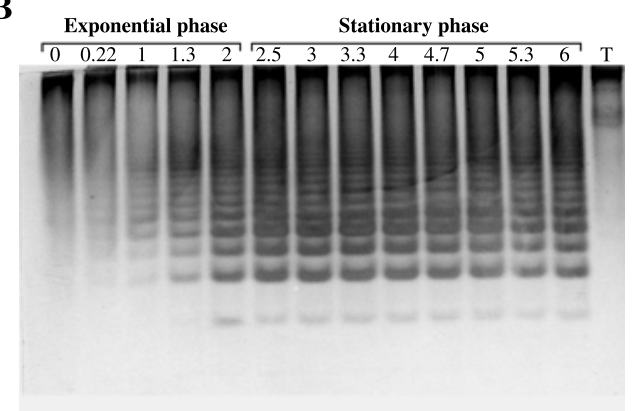

Fig. 2. Growth of the SW5 strain $(\mathbf{A})$, as seen from the culture optical density measured at $600 \mathrm{~nm}$. SW5 was grown in a 5 -L fermenter in the presence of ZoBell medium supplemented with fucoidan from Pelvetia canaliculata. (B) Fucoidanolytic activity in the culture supernatant was monitored using C-PAGE analysis. Culture aliquots $(2 \mathrm{ml})$ were centrifuged, supernatant aliquots $(20 \mu \mathrm{l})$ were incubated for $3 \mathrm{~h}$ with $100 \mu \mathrm{l}$ of $0.2 \%$ (wt/vol) fucoidan from $P$. canaliculata, and the hydrolysates (5 $\mu$ l aliquots) were analyzed by C-PAGE. Numbers above the lanes refer to the culture duration (in days), with $\mathrm{T}$ corresponding to unhydrolyzed fucoidan.

galacto-configuration (Lipkind et al., 1988; Bock and Thøgerson, 1982), cross-peaks were also observed between $\mathrm{H} 1$ of residue $\boldsymbol{b}$ and $\mathrm{H} 4$ of residue $\boldsymbol{d}$ and from $\mathrm{H} 1$ of $\boldsymbol{c}$ and $\mathrm{H} 4$ of residue $\boldsymbol{a}$. The HMBC spectrum (data not shown) corroborated the presence of $\alpha-1 \rightarrow 3$-and $\alpha-1 \rightarrow 4$-linked fucose. The anomeric protons of $\boldsymbol{b}, \boldsymbol{c}, \boldsymbol{d}$, at $5.40,5.39$, and $5.30 \mathrm{ppm}$, correlated with C3 of $\boldsymbol{d}$ and $\boldsymbol{a}$, at 73.6 and $74.8 \mathrm{ppm}$, and with C4 of $\boldsymbol{c}$, at $80.4 \mathrm{ppm}$ (Table 1). Conversely, the anomeric carbons $\boldsymbol{b} \mathbf{1}, \boldsymbol{c 1}$, and $\boldsymbol{d} \mathbf{1}$ correlated with protons $d \mathbf{3}, \boldsymbol{a} 3$, and $\boldsymbol{c} 4$, respectively. From these results, oligosaccharide 4 consists of the following carbon backbone: $\alpha$-L-Fucp-1 $1 \rightarrow 3-\alpha$-L-Fuc $p-1 \rightarrow 4-\alpha$-LFucp $-1 \rightarrow 3-\alpha / \beta-\mathrm{L}-\mathrm{Fuc} p$.

Protons of $\alpha$-L-fucopyranosyl units were identified from the COSY spectrum of oligosaccharide 3 and $\mathrm{C}$ chemical shifts were deduced from the
HMQC spectrum (Table 2). Chemical shifts were similar to those of oligosaccharide 4 , with the exception of two groups of signals $\left(\boldsymbol{c}^{\prime}\right.$ and $\left.\boldsymbol{d}^{\prime}\right)$, indicating the presence of an additional disaccharide unit in this oligosaccharide. The actual sequence of oligosaccharide 3 was deduced from its HMBC spectrum (Figure 6) and by comparison with $\mathrm{C}$ and $\mathrm{H}$ of oligosaccharide 4. HMBC showed cross-peaks from $\mathrm{H} 3$ of residues $\boldsymbol{d}, \boldsymbol{d}^{\prime}$, and $\boldsymbol{a}$ to $\mathrm{C} 1$ of residues $\boldsymbol{b}$,

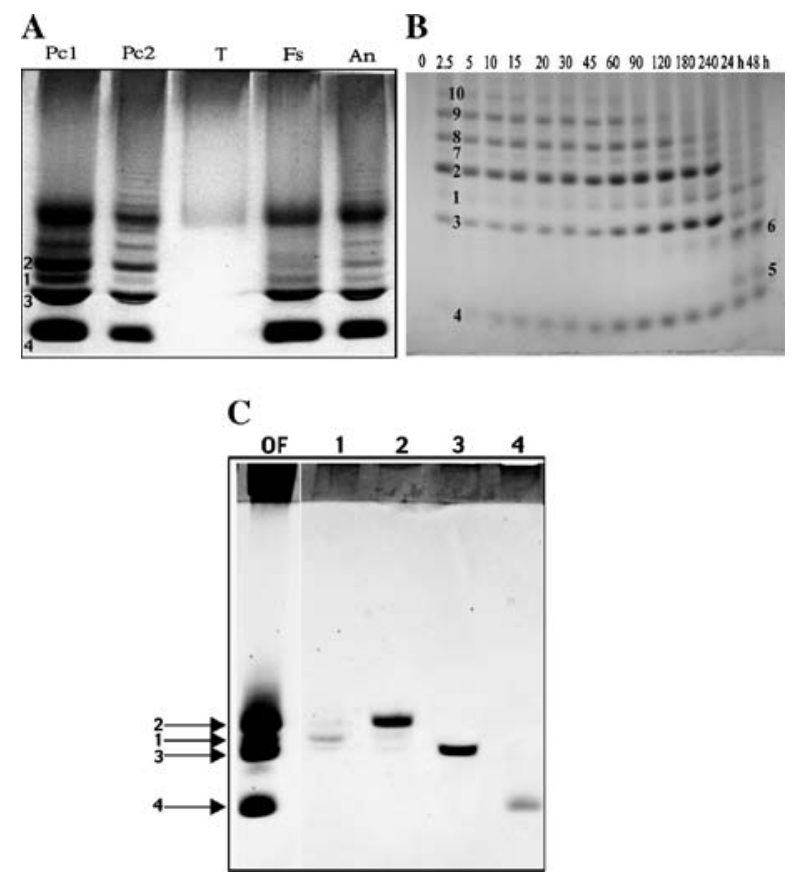

Fig. 3. (A) C-PAGE electrophoresis of the hydrolysates by SW5 ammonium sulfate fucoidanase fraction of various brown algal sulfated fucans $(0.5 \%)$ : the FS28 fraction of Pelvetia canaliculata fucoidan (Pc1), a CPC-purified fraction from the same species (Pc2), and fucoidans purified using CPC from Fucus spiralis (Fs) and Ascophyllum nodosum (An). The control ( $\mathrm{T}$ ) consisted of the FS28 fraction incubated with boiled enzyme. Bands numbers were assigned relative to their elution order on gel filtration (see Figure 4B) and by comparison with C. (B) C-PAGE analysis of the hydrolysis kinetics of $P$. canaliculata fucoidan (FS28) by SW5 ammonium sulfate fucoidanase fraction. The fucoidan $(400 \mu \mathrm{l}, 0.2 \%)$ was incubated with the ammonium sulfate enzyme fraction $(40 \mu 1)$ and aliquots $(20 \mu \mathrm{l})$ of this $\operatorname{mix}$ were boiled and electrophoresed as described previously. Band numbers were assigned by comparison to $A$ and $C$. Numbers at the top of the gel refer to the duration of hydrolysis (in minutes and hours). (C) C-PAGE analysis of purified low molecular weight fucoidans. P. canaliculata fucoidan (FS28) was hydrolyzed with SW5 fucanase and the products were recovered by ultrafiltration through a 500-Da membrane (OF fraction). This fraction was further purified by chromatography on DEAE Sepharose CL6B and then on Biogel P6, and carbohydrate-containing peaks 1, 2, 3, and 4 (see Figure 4B) were submitted to C-PAGE (lanes 1 to 4). Arrows indicate the corresponding oligosaccharide bands in the OF fraction. 
A

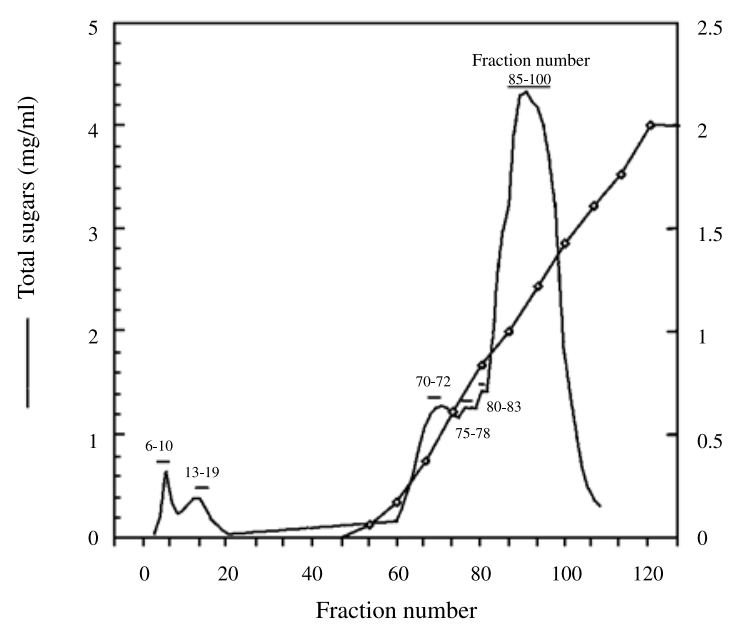

B

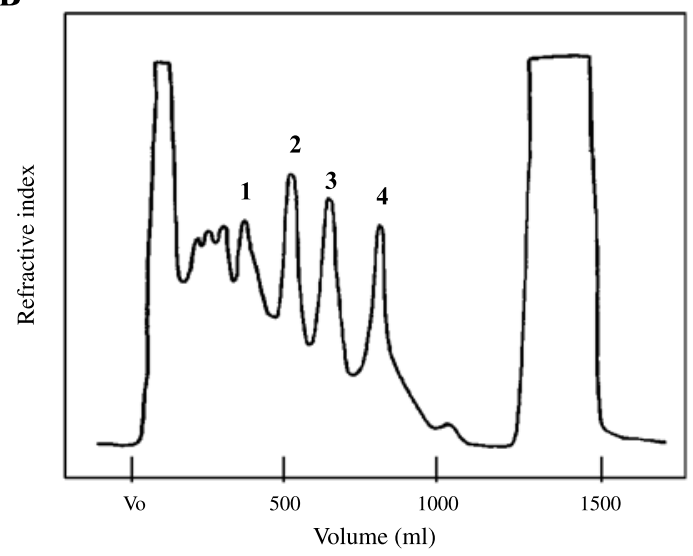

C

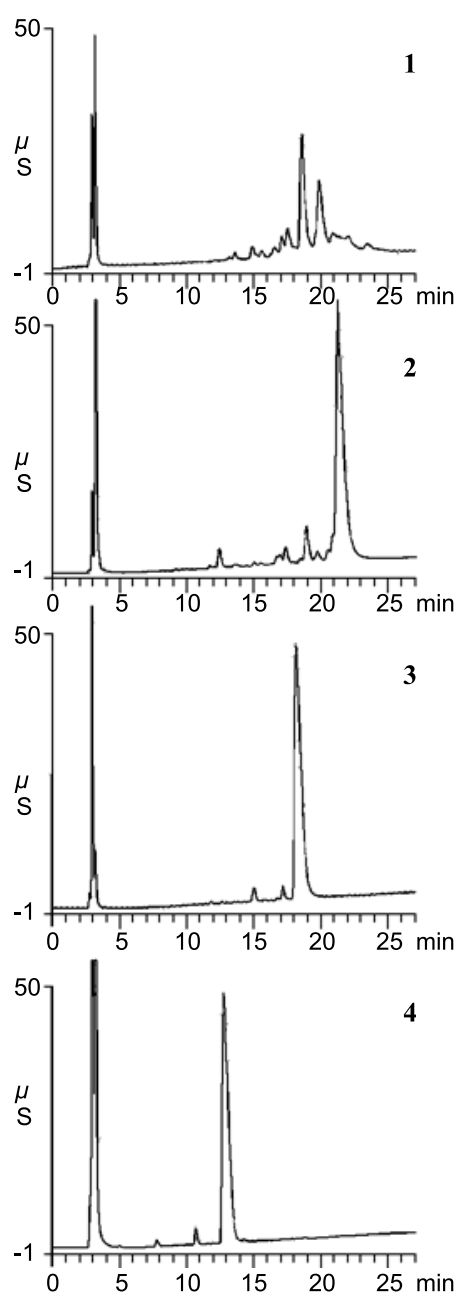

Fig. 4. Purification of the end-products of the hydrolysis of Pelvetia canaliculata fucoidan (FS28) by the SW5 ammonium sulfate fucanase fraction. (A) Fractionation of the hydrolysate (OF fraction) from P. canaliculata fucan on DEAE Sepharose. The OF fraction $(250 \mathrm{mg}$ ) was chromatographed on DEAE Sepharose CL6B with a 0 to $2 \mathrm{M} \mathrm{NaCl}$ gradient, eluted fractions were assayed for total sugars, and carbohydrate-containing fractions (fractions 85 to 100) were collected. (B) Fractions 85 to 100 were pooled and then chromatographed on Biogel P6 using $50 \mathrm{mM} \mathrm{NaNO3}$ as eluent. The four peaks resolved as fractions 1 to 4 were collected. (C) HPAEC elution profiles of peaks 1 to 4 from fractions 85 to 100 on Biogel P6 chromatography. Fractions were desalted on Sephadex G10 and injected at $250 \mu \mathrm{g} / \mathrm{ml}$ on an AS11A anion-exchange column, using a $\mathrm{NaOH}$ linear gradient and conductivity detection.

$\boldsymbol{c}$, and $\boldsymbol{c}^{\prime}$, and from $\mathrm{H} 4$ of residues $\boldsymbol{c}$ and $\boldsymbol{c}^{\prime}$ to $\mathrm{C} 1$ of residues $\boldsymbol{d}$ and $\boldsymbol{d}^{\prime}$. Cross-peaks between $\boldsymbol{c}, \boldsymbol{c}^{\prime}$ and $\boldsymbol{d}$, $\mathrm{d}^{\prime}$ corroborated the presence of $\alpha-1 \rightarrow 4$-linkages. However, it was not possible to specify whether the $\boldsymbol{c}^{\prime}$ - $\boldsymbol{d}^{\prime}$ units were close to the reducing end or the nonreducing end in the oligosaccharide. The proposed sequence for oligosaccharide 3 is $\alpha$-LFuc $p$ - $1 \rightarrow 3$ - $\alpha$-L-Fuc $p$ - $1 \rightarrow 4-\alpha$-L-Fuc $p$ - $1 \rightarrow 3$ - $\alpha$-L-Fuc $p$ $1 \rightarrow 4-\quad \alpha$-L-Fuc $p-1 \rightarrow 3-\alpha / \beta$-L-Fuc $p$.

The position of sulfate ester substituents in oligosaccharides 4 and 3 was deduced from the downfield shifts of $\mathrm{H} 2$ (0.7 to $0.9 \mathrm{ppm})$, which were consistent with those reported for the 2-O-sulfated fucans from the egg jelly layer echinoderms (VilelaSilva et al., 2002), and of C2 (4 to $5 \mathrm{ppm})$, relative to unsubstituted $\alpha$-L-Fucp residues (Table 3; Bock and Thøgerson, 1982). Sulfation on H3 of the 4-linked $\alpha$-L-Fucp 2-sulfate was deduced from the downfield shift observed for H3 ( 0.5 ppm) and C3 ( 9 ppm) of this residue compared with the same signals in 4-linked $\alpha$-L-Fucp-2-sulfate in Strongylocentrotus droebachiensis sea urchin fucan (Vilela-Silva et al., 2002). Furthermore, the proton and carbon chemical shifts for oligosaccharides 3 and 4 were in good agreement with those reported for alternating 3linked $\alpha$-L-Fucp-2-sulfate and 4-linked $\alpha$-L-Fucp-2,3disulfate in fucoidan oligomers from Ascophyllum nodosum (Chevolot et al., 2001).

Based on the attribution of the signals for proton of oligosaccharides 4 and 3, the mean degree of poly- 
Table 1. Chemical Shifts (ppm) for the Fucan Oligosaccharide 4

\begin{tabular}{lllllll}
\hline Residue & $H^{\mathrm{a}}$ & H2 & H3 & $H 4$ & $H 5$ & $H 6$ \\
\hline $\mathrm{a}(\alpha)$ & 5.51 & 4.55 & 4.08 & 4.11 & 4.25 & 1.25 \\
$\mathrm{e}(\beta)$ & 4.73 & 4.35 & 3.91 & 4.06 & 3.83 & 1.30 \\
$\mathrm{c}$ & 5.39 & 4.66 & 4.78 & 4.30 & 4.57 & 1.42 \\
$\mathrm{~d}$ & 5.30 & 4.60 & 4.22 & 4.14 & 4.46 & 1.31 \\
$\mathrm{~b}$ & 5.40 & 4.58 & 4.77 & 4.24 & 4.61 & 1.26 \\
& & & & & & \\
& $C 1^{\mathrm{b}}$ & $\mathrm{C} 2$ & $\mathrm{C3}$ & $\mathrm{C4}$ & $\mathrm{C5}$ & $\mathrm{C6}$ \\
\hline $\mathrm{a}(\alpha)$ & 91.68 & 74.53 & 74.84 & 70.28 & 67.08 & 16.60 \\
$\mathrm{e}(\beta)$ & 96.32 & 78.34 & 77.55 & 69.28 & 71.76 & $\sim 16.6$ \\
$\mathrm{c}$ & 96.18 & 73.61 & 75.05 & 80.38 & 69.03 & 16.78 \\
$\mathrm{~d}$ & 99.86 & 76.53 & 73.61 & 70.56 & 68.20 & 16.46 \\
$\mathrm{~b}$ & 95.81 & 73.52 & 75.05 & 71.76 & 67.693 & 16.38 \\
\hline
\end{tabular}

${ }^{\mathrm{a}}$ The ${ }^{1} \mathrm{H}$ spectrum was recorded at $400 \mathrm{MHz}, 298 \mathrm{~K}$, chemical shifts are relative to internal $\delta^{1} \mathrm{H}$ acetone 2.225.

${ }^{\mathrm{b}}$ The ${ }^{13} \mathrm{C}$ spectrum was recorded at $400 \mathrm{MHz}, 298 \mathrm{~K}$, chemical shifts are relative to internal $\delta^{13} \mathrm{C}$ acetone 31.45 .

merization (DP) was estimated from the sum of the integral of $\mathrm{H} 1$ of the reducing-end sugar $\boldsymbol{a}(\alpha$-configuration) and $\mathrm{H} 5$ of the reducing-end sugar $\boldsymbol{e}(\beta-$ configuration) or that of $\mathrm{H} 1$ of $\boldsymbol{a}$ and (H5 $+\mathrm{H} 3) / 2$ of $\boldsymbol{e}$, in order to establish the integral value of one proton $(\boldsymbol{H})$. The number of internal fucose residues (i.e., excluding nonreducing residue) $(\boldsymbol{B})$ was estimated from the integral of signals between 5.25 and 5.40

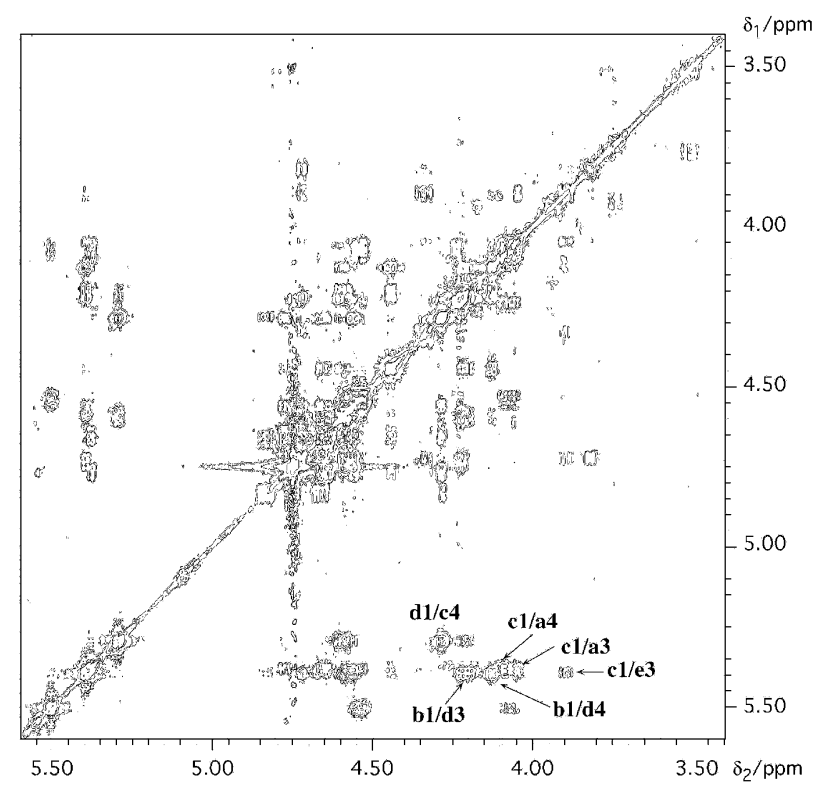

Fig. 5. Expansion of the double ${ }^{1} \mathrm{H}-{ }^{1} \mathrm{H}$ ROESY spectrum of oligosaccharide 4 , at $400 \mathrm{MHz}, 25^{\circ} \mathrm{C}$, in $\mathrm{D}_{2} \mathrm{O}$. Cross-peaks between the various sugar residues are indicated as, for example: $\boldsymbol{d 1} / \boldsymbol{c} \boldsymbol{4}$ for $\mathrm{H} 1$ of unit $\boldsymbol{d}$ with $\mathrm{H} 4$ of unit $\boldsymbol{c} .1024$ experiments of 2000 data points and eight transients each with a recycling time of $1.16 \mathrm{~s}$ were recorded and transformed on $2 \times 2 \mathrm{~K}$ data points with unshifted sine bell multiplication in both dimensions. The ROESY spinlock pulse duration was $700 \mathrm{~ms}$.
Table 2. Chemical Shifts (ppm) for the Fucan Oligosaccharide 3

\begin{tabular}{lllllll}
\hline Residue & $H 1^{\mathrm{a}}$ & $H 2$ & $H 3$ & $H 4$ & $H 5$ & $H 6$ \\
\hline $\mathrm{a}(\alpha)$ & 5.49 & 4.53 & 4.07 & 4.10 & 4.23 & 1.24 \\
$\mathrm{e}(\beta)$ & 4.72 & 4.33 & 3.90 & 4.05 & 3.82 & 1.28 \\
$\mathrm{c}^{\prime}$ & 5.39 & 4.64 & 4.76 & 4.28 & 4.56 & 1.40 \\
$\mathrm{~d}^{\prime}$ & 5.30 & 4.58 & 4.22 & 4.13 & 4.39 & 1.30 \\
$\mathrm{c}$ & 5.40 & 4.65 & 4.79 & 4.29 & 4.62 & 1.40 \\
$\mathrm{~d}$ & 5.29 & 4.58 & 4.22 & 4.13 & 4.43 & 1.30 \\
$\mathrm{~b}$ & 5.39 & 4.57 & 4.73 & 4.22 & 4.59 & 1.25 \\
& & & & & & \\
& $C 1^{\mathrm{b}}$ & $C 2$ & $C 3$ & $C 4$ & $C 5$ & $C 6$ \\
\hline $\mathrm{a}(\alpha)$ & 91.64 & 74.57 & 74.57 & 70.16 & 67.06 & 16.56 \\
$\mathrm{e}(\beta)^{\star}$ & & & & & & \\
$\mathrm{c}^{\prime}$ & 95.73 & 73.57 & 75.06 & 80.87 & 68.98 & 16.76 \\
$\mathrm{~d}^{\prime}$ & 100.04 & 74.57 & 74.57 & 70.53 & 68.15 & 16.43 \\
$\mathrm{c}$ & 95.96 & 73.57 & 75.06 & 80.58 & 68.98 & 16.76 \\
$\mathrm{~d}$ & 99.87 & 74.57 & 74.57 & 70.53 & 68.15 & 16.43 \\
$\mathrm{~b}$ & 95.96 & 73.57 & 76.18 & 71.73 & 67.68 & 16.43 \\
\hline
\end{tabular}

${ }^{a}$ The ${ }^{1} \mathrm{H}$ spectrum was recorded at $400 \mathrm{MHz}, 298 \mathrm{~K}$, chemical shifts are relative to internal $\delta^{1} \mathrm{H}$ acetone 2.225 .

${ }^{b}$ The $13 \mathrm{C}$ spectrum was recorded at $400 \mathrm{MHz}, 298 \mathrm{~K}$, chemical shifts are relative to internal $\delta^{13} \mathrm{C}$ acetone 31.45 .

${ }^{\star}$ Not determined.

ppm divided by the integral value for one proton $(\boldsymbol{B})$ $\mathbf{H})$. The DP value was then calculated as $(\boldsymbol{B} / \boldsymbol{H})+1$. Using this calculation, oligosaccharides 4,3 , and 2, have a mean DP of 3.9, 5.9, and 6.8, respectively. The proton nuclear magnetic resonance (NMR) spectrum of oligosaccharide 2 indicated that the mixture did not contain oligosaccharides in the series homologous to oligosaccharides 4 and 3 .

\section{Discussion}

The SW5 Strain Is a Fucoidanolytic Flavobacteriaceae. We here report the isolation from the effluent treatment facility of an alginate plant of a novel bacterium referred to as SW5, which exhibits fucoidanase activity when grown in the presence of sulfated fucans from the fucoid Pelvetia canaliculata (Figure 2). The occurrence of such a fucoidanolytic bacterium in this habitat is likely to be accounted for by the presence of significant amounts of high molecular weight sulfated fucoidans in these effluents, as byproducts of the alginate-manufacturing process from fucoidan-containing brown algae such as Laminaria digitata and Ascophyllum nodosum (Fleury and Lahaye, 1993).

Based on its physiological and biochemical characteristics as well as on the phylogenetic analysis of its 16S rDNA gene (Figure 1), SW5 belongs in the order of Flavobacteriales and in the family Flavobacteriaceae. However, it is only remotely related to the only other fucoidan-degrading Flavobacteriaceae characterized so far, "Fucobacter marina" (Sakai et al., 2002). It is closely related to, 


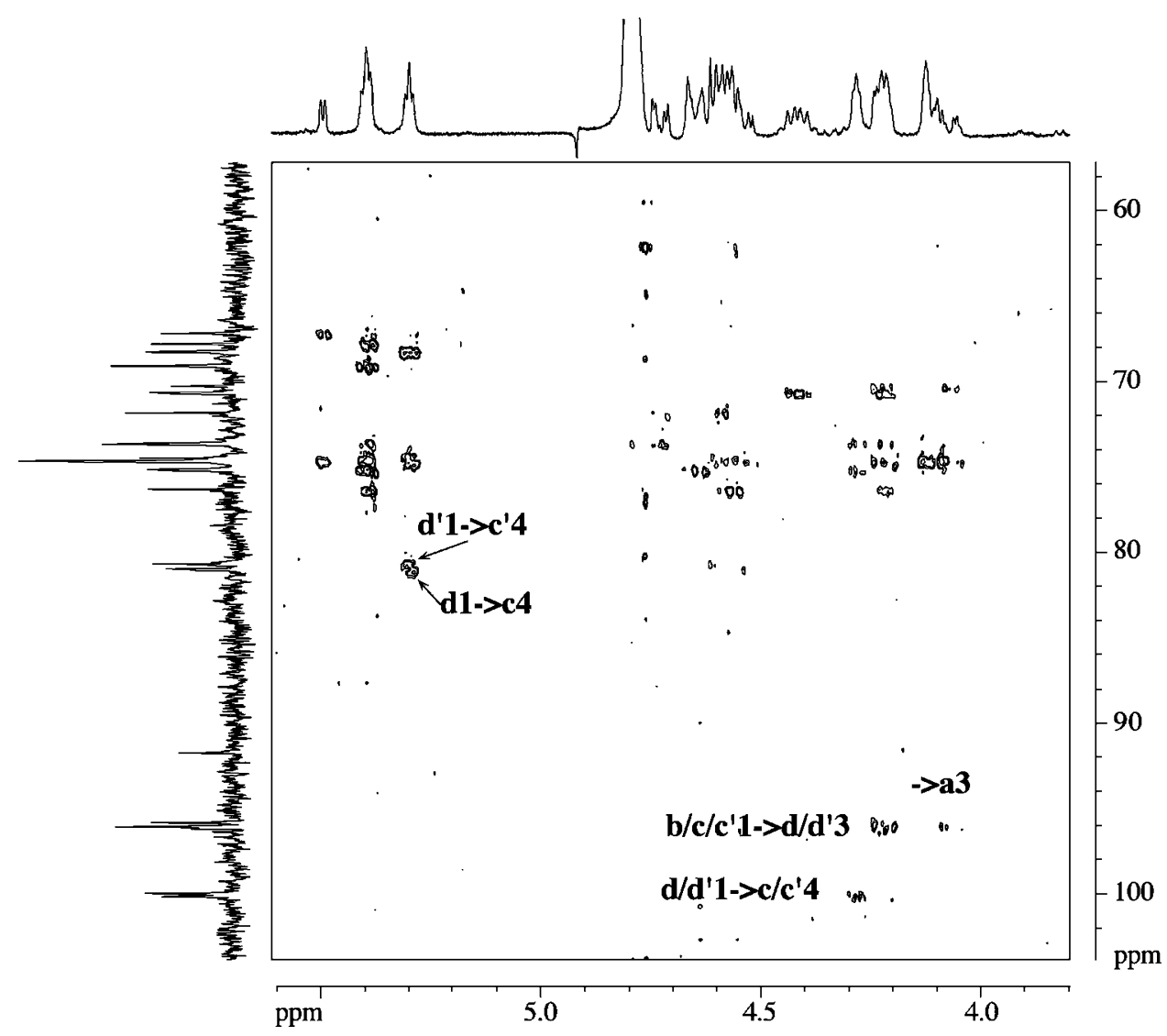

Fig. 6. Expansion of the double ${ }^{1} \mathrm{H}^{-13} \mathrm{C} \mathrm{HMBC}$ spectrum of oligosaccharide 3 , at $400 \mathrm{MHz}, 25^{\circ} \mathrm{C}$, in $\mathrm{D}_{2} \mathrm{O}$. Cross-peaks between the various sugar residues are indicated using the same nomenclature as in Figure 5. 512 experiments of 2000 data points and 64 transients, each with a recycling time of $1.2 \mathrm{~s}$, were recorded and transformed on $1 \times 2 \mathrm{~K}$ data points on the F1 and F2 dimensions, respectively after exponential multiplication in F1 (line broadening of $0.1 \mathrm{~Hz}$ ) and unshifted sine bell multiplication in F2. The evolution time for long range interactions was set at $75 \mathrm{~ms}$.

but distinct from, the genera Gelidibacter and Psychroserpens, which were isolated from an Antartic sea-ice habitat (Bowman et al., 1997). All of these bacterial strains require the presence of salt for optimal growth, suggesting that they are marine in origin. Therefore, SW5 may have been a member of the natural epiflora of brown algae carried throughout the alginate-extraction process and seeded into the water-treatment muds, where it contributes to the depolymerisation of the sulfated fucoidans in the effluents. Alternatively, since the water treatment facility is located close to an estuary, SW5 may have been naturally introduced from the nearby estuarine bacterial communities.

SW5 Secretes Fucoidan Hydrolase Activity. The bacterium extracellular enzymes were subjected to fractionation by ammonium sulfate precipitation. The sulfated fucoidan from P. canaliculata was extensively degraded by the fraction of SW5 extracellular enzymes which precipitates between $40 \%$ and $60 \%$ ammonium sulfate saturation (Figure 3A). Fucoidan was first cleaved into a number of high molecular weight fucoidan oligosacchar-

Table 3. Comparison of the Chemical Shifts of Various Fucans

\begin{tabular}{|c|c|c|c|c|c|c|}
\hline & H1 & H2 & H3 & H4 & H5 & H6 \\
\hline Desulfated sea cucumber fucan ${ }^{\mathrm{a}}$ & 5.08 & 3.92 & 4.00 & nd & 4.27 & 1.21 \\
\hline native sea cucumber fucan, residue $\mathrm{A}^{\mathrm{a}}$ & 5.40 & 4.58 & 4.39 & 4.91 & 4.37 & 1.25 \\
\hline$\alpha$-L-Fucose & 5.2 & 3.8 & 3.8 & 3.8 & 4.2 & 1.2 \\
\hline$\alpha$-L-Fucose residues of fucan oligosaccharides 3 and 4 & $4.7-5.5$ & $4.4-4.7$ & $3.9-4.0$ & $4.0-4.1$ & $3.8-4.2$ & $1.2-1.3$ \\
\hline
\end{tabular}

${ }^{\mathrm{a}}$ Data from Ludwigothurea grisea. 
ides (Figure $3 \mathrm{~B}$ ), suggesting that this enzyme fraction contains hydrolases which randomly attack fucoidan chains.

As shown by DEAE chromatography and gel filtration followed by C-PAGE, HPAEC, and NMR analysis, the hydrolysis products contained a tetrasaccharide, $\alpha$-L-Fuc $p-2,3-\left(\operatorname{diOSO}_{3}\right)-1 \rightarrow 3-\alpha-\mathrm{L}-$ Fucp-2- $\left(\mathrm{OSO}_{3}\right)-1 \rightarrow 4-\alpha-\mathrm{L}-\mathrm{Fuc} p-2,3-\left(\mathrm{diOSO}_{3}\right)-1 \rightarrow 3-\alpha-\mathrm{L}-$ Fucp-2- $\left(\mathrm{OSO}_{3}\right)$, and a hexasaccharide, $\alpha$-L-Fucp-2, 3 - $\left(\right.$ diOSO$\left._{3}\right)-1 \rightarrow 3-\alpha$-L-Fucp-2- $\left(\mathrm{OSO}_{3}\right)-1 \rightarrow 4$ - $\alpha$-L-Fucp2,3 - $\left(\mathrm{diOSO}_{3}\right)-1 \rightarrow 3$ - $\alpha$-L-Fucp-2-(OSO$\left.)_{3}\right)-1 \rightarrow 4-\alpha$-L-Fucp2,3 -( $\left.\mathrm{diOSO}_{3}\right)-1 \rightarrow 3$ - $\alpha$-L-Fucp-2- $\left(\mathrm{OSO}_{3}\right)$, as well as higher molecular-weight fucoidan oligosaccharides. These findings are similar to those reported from a low molecular weight fucan fraction of $A$. nodosum (Chevolot et al., 2001), which harbors repetitions of the disaccharide $1 \rightarrow 3-\alpha$-L-Fuc $p-2\left(\mathrm{OSO}_{3}\right)-1 \rightarrow 4-\alpha$-LFucp-2,3( $\left.\mathrm{diOSO}_{3}\right)$, referred to as B-A and where the $\mathrm{B}$ fucosyl residue can more or less regularly bear a substituent at C-4 (sulfate, xylose, fucose or sulfated fucose). Similar fucan oligosaccharides with repeating units were also recognized in the fucoidans of F. vesiculosus (Chevolot et al., 2001), F. evanescens (Bilan et al., 2002) and F. distichus (Bilan et al., 2004). Since SW5 extracellular enzymes can degrade a variety of sulfated fucoidans from fucoid algae (Figure 3A), it is thus likely that the bacterium attacks fucoidan by cleaving linkages within blocks of alternating $\alpha-1 \rightarrow 3$ and $\alpha-1 \rightarrow 4$ L-sulfated fucose residues. This conclusion is only preliminary, however, since SW5 is likely to possess multiple fucoidan degradative activities, as suggested by the presence of different low molecular weight fucoidans at completion of the hydrolysis of $P$. canaliculata fucoidan (Figure 3B). Altogether it appears that SW5 features a fucoidan-degrading enzyme machinery distinct from that of "Fucobacter mari$n a^{\prime \prime}$, which exhibits a fucoglucuronomannan lyase (Sakai et al., 2002, 2003a). Other fucoidan-degrading activities were reported from intracellular extracts of Fucophilus fucoidanolyticus, namely a fucoidan hydrolase, an $\alpha$-D-glucuronidase and a fucose-deacetylase (Sakai et al., 2003b,c). The isolation of SW5 provides an alternative source for the production of extracellular enzymes to degrade fucoidan.

In conclusion, on the basis of its capacity to degrade brown algal sulfated fucoidans, we have isolated a flavobacteriacean strain, referred to as SW5, which secretes fucoidan-hydrolase activity in its culture medium. The end products of the degradation of $P$. canaliculata fucoidan comprised a tetrasaccharide, made of the repetition of two units of $\alpha$-1 $\rightarrow 3$-L-fucopyranose-2-sulfate, and $\alpha-1 \rightarrow 4$-Lfucopyranose-2,3-disulfate, with the 3-linked residues at the nonreducing end, and a hexasaccharide in the same homologous series. SW5 has now been successfully maintained for more than 5 years in our laboratory, where it is routinely used for the preparation of fucoidan-degrading enzymes. The strain was patented (Descamps et al., 1998) and deposited in the DSMZ bacterial collection, under the accession number 12171. SW5 fucoidan endohydrolase(s) should prove a useful tool for the preparation of biologically active low molecular weight fucans as well an interesting novel material for the isolation of enzymes for the structural analysis of fucoidans.

\section{Acknowledgments}

V.D. and S.C. were the recipients of a PhD fellowship co-funded by the ANRT, whose help is gratefully acknowledged. The authors also are grateful to the late J.-C. Pasquier for access to the water treatment facilities of Danisco Cultor Landerneau SA, and to Erwan Corre, for his expertise in phylogenetic analyses.

\section{References}

Barbeyron T, L'Haridon S, Corre E, Kloareg B, Potin P (2001) Zobellia galactanovorans gen. nov., sp. nov., a marine species of Flavobacteriaceae isolated from a red alga, and classification of [Cytophaga] uliginosa (ZoBell and Upham, 1944) Reichenbach 1989 as Zobellia uliginosa gen. nov., comb. nov. Int J Syst Evol Microbiol 51, 985-997

Béress A, Wassermann O, Bruhn T, Béress L (1993) A new procedure for the isolation of anti-HIV compounds (polysaccharides and polyphenols) from the marine alga Fucus vesiculosus. J Nat Prod 56, 478-488

Berteau O, McCort I, Goasdoue N, Tissot B, Daniel R (2002) Characterization of a new alpha-l-fucosidase isolated from the marine mollusk Pecten maximus that catalyzes the hydrolysis of alpha-l-fucose from algal fucoidan (Ascophyllum nodosum). Glycobiology 12, 273-282

Bilan MI, Grachev AA, Ustuzhanina NE, Shashkov AS, Nifantiev NE, Usov AI (2002) Structure of a fucoidan from the brown seaweed Fucus evanescens C. Ag. Carbohydr Res 337, 719-730

Bilan MI, Grachev AA, Ustuzhanina NE, Shashkov AS, Nifantiev NE, Usov AI (2004) A highly regular fraction of a fucoidan from the brown seaweed Fucus distichus L. Carbohydr Res 339, 511-517

Blakeney AB, Harris PJ, Henry RJ, Stone BA (1983) A simple and rapid preparation of alditol acetates for monosaccharide analysis. Carbohydr Res 113, 291-299

Blumenkrantz N, Asboe-Hansen G (1973) New method for quantitative determination of uronic acids. Anal Biochem 54, 484-486

Bock K, Thøgerson H (1982) Nuclear magnetic resonance 
spectroscopy in the study of mono-and oligosaccharides. Annu Rep NMR Spectrosc 13, 2-57

Bock K, Pedersen C, Pedersen H (1984) Carbon-13 nuclear magnetic resonance data for oligosaccharides. Adv Carbohydr Chem Biochem 42, 193-225

Bowman JP, Mc Cammon SA, Brown JL, Nichols PD, McMeekin TA (1997) Psychroserpens burtonensis gen.nov., sp. nov., and Gelidibacter algens gen. nov., sp. nov., psychrophilic bacteria isolated from antarctic lacustrine and sea ice habitats. Int J Syst Bact 54, 670677

Chevolot L, Mulloy B, Ratiskol J, Foucault A, ColliecJouault S (2001) A disaccharide repeat unit is the major structure in fucoidans from two species of brown algae. Carbohydr Res 330, 529-535

Dalton JP, Hudson D, Adams JH, Miller LH (1991) Blocking of the receptor-mediated invasion of erythrocytes by Plasmodium knowlesi malaria with sulfated polysaccharides and glycosaminoglycans. Eur J Biochem 195, 789-794

Daniel R, Berteau O, Jozefonvicz J, Goasdoue N (1999) Degradation of algal (Ascophyllum nodosum) fucoidan by an enzymatic activity contained in digestive glands of the marine mollusc Pecten maximus. Carbohydr Res 322, 291-297

Descamps V, Klarzynski O, Barbeyron T, Kloareg B, Fritig B, Joubert J-M, Plesse B, Yvin J-C (1998). "Fucooligosaccharides, enzyme pour leur préparation à partir des fucanes, bactérie productrice de l'enzyme et applications des fuco-oligosaccharides à la protection des plantes." Patent no. FR9811756, no. WOFR9902243.

Disches Z, Schettles LB (1948) A specific color reaction of methyl-pentoses and a spectrophotometric micromethod for their determination. J Biol Chem 175, 595-603

Fleury N, Lahaye M (1993) Studies on by-products from the industrial extraction of alginate. J Appl Phycol 5, 605614

Furukawa S, Fujikawa T, Koga D, Ide A (1992) Production of fucoidan-degrading enzymes, fucoidanase and fucoidan sulfatase by Vibrio sp. N-5. Nippon Suisan Gakkaishi 58, 1499-1503

Goodner BW, Quatrano RS (1993) Fucus embryogenesis, a model to study the establishment of polarity. Plant Cell 5, 1471-1481

Hicks RE, Amann RI, Stahl DA (1992) Dual staining of natural bacterioplankton with 4',6-diamdino-2-phenylindole and fluorescent oligonucleotide probes targeting kingdom-level 16S rRNA sequences. Appl Environ Microbiol 58, 2158-2163

Hoshino T, Hayashi T, Hayashi J, Lee JB, Sankawa U (1998) An antivirally active sulfated polysaccharide from Sargassum horneri (Turner) C. Agardh. Biol Pharm Bull 21, 730-734

Hugh R, Leifson E (1953) The taxonomic significance of fermentative versus oxydative metabolism of carbohydrates by various Gram-negative bacteria. J Bacteriol $66,24-26$

Kane MD, Poulsen LK, Stahl DA (1993) Monitoring the enrichment and isolation of sulfate-reducing bacteria by using oligonucleotide hybridization probes designed from environmentally derived 16S rRNA sequences. Appl Environ Microbiol 59, 682-686

Kidby DK, Davidson DJ (1973) A convenient ferricyanide estimation of reducing sugars in the nanomole range. Anal Biochem 55, 321-325

Kitamikado M, Yamaguchi K, Tseng CH, Okabe B (1990) Method designed to detect alginate-degrading bacteria. Appl Environ Microbiol 9, 2939-2940

Kitamura K, Matsuo M, Yasui T (1992) Enzymic degradation of fucoidan by fucoidanase from the hepatopancreas of Patinopecten yessoensis. Biosci Biotechnol Biochem 56, 490-494

Klarzynski O, Descamps V, Plesse B, Yvin J-C, Kloareg B, Fritig B (2003) Sulfated fucan oligosaccharides elicit defense responses in tobacco and local and systemic resistance against tobacco mosaic virus. Mol PlantMicrob Interact 16, 115-122

Kloareg B (1984) Isolation and analysis of cell walls of brown algae Pelvetia canaliculata and Ascophyllum nodosum. Physiol Veg 22, 47-56

Kloareg B, Quatrano RS (1988) Structure of the cell walls of marine algae and ecophysiological functions of the matrix polysaccharides. Oceanogr Mar Biol Annu Rev 26, 259-315

Kropf DL, Kloareg B, Quatrano RS (1988) Cell wall is required for fixation of the embryonic axis in Fucus zygotes. Science 239, 187-189

Ley K, Linneman G, Meinen M, Stoolman LM, Gaehtgens P (1993) Fucoidin, but not yeast polyphosphomannan PPME, inhibits leukocyte rolling in venules of the rat mesentery. Blood 81, 177-185

Linneman G, Reinhart K, Parade U, Philipp A, Pfister W, Straube E, Karzai W (2000) The effects of inhibiting leukocyte migration with fucoidin in a rat peritonitis model. Intensive Care Med 26, 1540-1546

Lipkind GM, Shashkov AS, Mamyan SS, Kochetkov NK (1988) The nuclear overhauser effect and structural factors determining the conformations of disaccharide glycosides. Carbohydr Res 181, 1-12

Logeart D, Prigent-Richard S, Jozefonvicz J, Letourneur D (1997) Fucans, sulfated polysaccharides extracted from brown seaweeds, inhibit vascular smooth muscle cell proliferation. I. Comparison with heparin for antiproliferative activity, binding and internalization. Eur J Cell Biol 74, 376-384

Mabeau S, Kloareg B (1987) Isolation and analysis of the cell walls of brown algae, Fucus spiralis, F. ceranoides, F. vesiculosus, F. serratus, Bifurcaria bifurcata and Laminaria digitata. J Exp Bot 38, 1573-1580

Mabeau S, Kloareg B, Joseleau J-P (1990) Fractionation and analysis of fucans from brown algae. Phytochemistry 29, 2441-2445

Mahony MC, Oehninger S, Clark GF, Acosta AA, Hodgen GD (1991) Fucoidin inhibits the zona pellucida-induced acrosome reaction in human spermatozoa. Contraception 44, 657-665

Mahony MC, Clarck GF, Oehninger S, Acosta AA, Hodgen GD (1993) Fucoidin binding activity and its localization on human spermatozoa. Contraception 48, 277-288 
Maniatis T, Fritsch EF, Sambrook J (1982) Molecular Cloning, A. Laboratory Manual. (Cold Spring Harbor, New York: Cold Spring Harbor Laboratory Press)

Mayer AMS, Diaz A, Pesce A, Criscuolo M, Groisman JF, de Lederkremer RM (1987) Biological activity in Macrocystis pirifera from Argentina, sodium alginate, fucoidan and laminaran. III. Antiviral activity. Hydrobiologia 151/152, 497-500

McCaffrey TA, Falcone DJ, Borth W, Brayton CF, Weksler BB (1992) Fucoidan is a non-coagulant inhibitor of intimal hyperplasia. Biochem Biophys Res Commun 184, 773-781

Millet J, Colliec-Jouault S, Mauray S, Theveniaux J, Sternberg C, Boisson-Vidal C, Fischer AM (1999) Antithrombotic and anticoagulant activities of a low molecular weight fucoidan by the subcutaneous route. Thromb Haemost 81, 391-395

Min H, Cowman MK (1986) Combined alcian blue and silver staining of glycosaminoglycans in polyacrylamide gels, application to electrophoretic analysis of molecular weight distribution. Anal Biochem 155, 275-285

Morigana T, Araki T, Ito M, Kitamikado M (1981) A search for fucoidan-degrading bacteria in coastal sea environments of Japan. Bull Jpn Soc Sci Fish 47, 621-625

Ostergaard C, Yieng-Kow RV, Benfield T, Frimodt-Moller N, Espersen F, Lundgren JD (2000) Inhibition of leukocyte entry into the brain by the selectin blocker fucoidin decreases interleukin-1 (IL-1) levels but increases IL-8 levels in cerebrospinal fluid during experimental pneumococcal meningitis in rabbits. Infect Immun 68, 3153-3157

Pereira MS, Mulloy B, Mourão PAS (1999) Structure and anticoagulant activity of sulfated fucans. J Biol Chem 274, 7656-7667

Reichenbach H, Kleinig H, Achenbach H (1974) The pigment of Flexibacter elegans, novel and chemosystematically useful coumpounds. Arch Microbiol 101, 131-144

Riou D, Colliec-Jouault S, Pinczon du sel D, Bôsch S, Siavoshian S, LeBert V, Tomasoni C, Sinquin C, Durand P, Roussakis C (1996) Antitumor and antiproliferative effects of a fucan extracted from Ascophyllum nodosum against a non-small-cell bronchopulmonary carcinoma line. Anticancer Res 16, 1213-1218

Sakai T, Kimura H, Kato I (2002) A marine strain of Flavobacteriaceae utilizes brown seaweed fucoidan. Mar Biotechnol 4, 399-405

Sakai T, Kimura H, Kojima K, Shimanaka K, Ikai K, Kato I (2003a) Marine bacterial sulfated fucoglucuronomannan (SFGM) lyase digests brown algal SFGM into trisaccharides. Mar Biotechnol 5, 70-78
Sakai T, Ishizuka K, Kato I (2003b) Isolation and characterization of a fucoidan-degrading marine bacterium. Mar Biotechnol 5, 409-416

Sakai T, Ishizuka K, Shimanaka K, Ikai K, Kato I (2003c) Structures of oligosaccharides derived from Cladosiphon okamuranus fucoidan by digestion with marine bacterial enzymes. Mar Biotechnol 5, 536-544

Smibert RM, Krieg NR (1981) "General characterization". In: Manual of Methods for General Bacteriology, Gerhardt P, Murray RGE, Costilow RN, Nester EW, Wood WA, Krieg NR, Phillips GB, eds. (Washington, DC: American Society for Microbiologyl pp 409-443

Thanassi NM, Nakada HI (1967) Enzymic degradation of fucoidan by enzymes from the hepatopancreas of abalone, Haliotis species. Arch Biochem Biophys 118, 172-177

Thibault JF (1979) Automatisation du dosage des substances pectiques par la méthode du méta-hydroxyphényl. Lebenssm-Wiss Technol 12, 247-251

Thorlacius H, Vollmar B, Seyfert UT, Vestweber D, Menger MD (2000) The polysaccharide fucoidan inhibits microvascular thrombus formation independently from P- and L-selectin function in vivo. Eur J Clin Invest 30, 804-810

Tillmans J, Phillipi K (1929) The carbohydrate content of the important protein of foodstuff on colorimetric procedure for the determination of nitrogen free sugars in protein. Biochem Z 215, 36-60

Uchida M (1995) Enzyme activities of marine bacteria involved in Laminaria-thallus decomposition and the resulting sugar release. Mar Biol 123, 639-644

Vilela-Silva ACES, Castro MO, Valente AP, Biermann CH, Mourao PAS (2002) Sulfated fucans form the egg jellies of the closely related sea urchins Strongylocentrotus droebachiensis and Strongylocentrotus pallidus ensure species-specific fertilization. J Biol Chem 277, 379-387

Wikström T, Braide M, Bagge U, Risberg B (1995) Leukocyte margination during hemorragic shock correlates to preshock margination and is reduced by fucoidin. Shock 3, 40-45

Zablackis E, Perez J (1990) A partially pyruvated carrageenan from Hawaiian Grateloupia filicina (Cryptonemiales Rhodophyta). Bot Mar 33, 273-276

Zhuang C, Itoh H, Mizuno T, Ito H (1995) Antitumor active fucoidan from the brown seaweed, Umitoranoo (Sargassum thunbergii). Biosci Biotechnol Biochem 59, 563-567

ZoBell CE (1941) Studies on marine bacteria. I. The cultural requirements of heterotrophic aerobes. J Mar Res 4, $41-75$ 